\title{
Intersections
}

Canadian Journal of Music

Revue canadienne de musique

\section{Dylan Robinson. 2020. Hungry Listening: Resonant Theory for Indigenous Sound Studies. Minneapolis: University of Minnesota Press. 319 pp. ISBN 978-1-5179-0768-6 (hardcover), ISBN 978-1-5179-0769-3 (paperback)}

\section{Rena Roussin}

Volume 39, numéro 1, 2019

URI : https://id.erudit.org/iderudit/1075348ar

DOI : https://doi.org/10.7202/1075348ar

Aller au sommaire du numéro

Éditeur(s)

Canadian University Music Society / Société de musique des universités canadiennes

ISSN

1918-512X (numérique)

Découvrir la revue

Citer ce compte rendu

Roussin, R. (2019). Compte rendu de [Dylan Robinson. 2020. Hungry Listening: Resonant Theory for Indigenous Sound Studies. Minneapolis: University of Minnesota Press. 319 pp. ISBN 978-1-5179-0768-6 (hardcover),

ISBN 978-1-5179-0769-3 (paperback)]. Intersections, 39(1), 145-149.

https://doi.org/10.7202/1075348ar

(c) Canadian University Music Society / Société de musique des universités canadiennes, 2021
Ce document est protégé par la loi sur le droit d'auteur. L'utilisation des services d'Érudit (y compris la reproduction) est assujettie à sa politique d'utilisation que vous pouvez consulter en ligne.

https://apropos.erudit.org/fr/usagers/politique-dutilisation/ 


\section{BOOK REVIEW}

Dylan Robinson. 2020. Hungry Listening: Resonant Theory for Indigenous Sound Studies. Minneapolis: University of Minnesota Press. 319 pp. ISBN 9781-5179-0768-6 (hardcover), ISBN 978-1-5179-0769-3 (paperback)

It is challenging to convey the significance of the contribution Dylan Robinson has made to music, sound, and Indigenous scholarship through Hungry Listening. This book could-indeed, should-profoundly change the ways scholars of music and sound think about cultures of listening and what it means to compose, listen to, perform, and teach music (Indigenous and otherwise) in the Canadian nation-state. Published as part of the University of Minnesota Press's Indigenous Americas Series, Hungry Listening draws on Robinson's lived experiences as a Stó:lō man and his extensive research and artistic work as an associate professor (and Canada Research Chair) of Indigenous Studies at Queen's University. The book

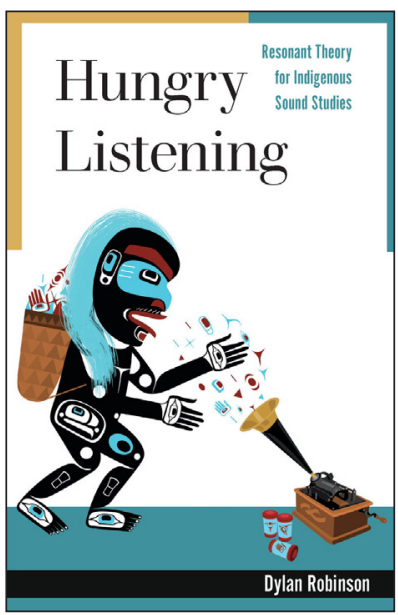
presents a comprehensive overview of the ways in which Indigenous music interacts with art music and Western academia amid Canada's efforts to realize reconciliation. Hungry Listening is in good company as one of many sources that considers decolonized approaches to the arts, post-secondary education, and research (see Cote-Meek 2014; Hoefnagels and Diamond 2012; Robinson and Martin 2016; and Wilson 2015 for several examples), yet nevertheless marks an important moment in music and sound studies as, to my knowledge, the first monograph on interactions between Indigenous music and art music on Turtle Island (North America) written by an Indigenous person.

The term "hungry listening" comes from two Halq'eméylem words: $\operatorname{sh} x$ welitemlh, an adjective for a settler or white person's methods and things, and xwélalà:m, the word for listening. Importantly, shxwelitemlh draws on xwelitem, which means "white settler," and translates to "starving person," as white settlers first came to Stó:lō lands in a state of starvation (2). Robinson uses these words "individually and together ... in order to address 
positionalities of the listening encounter (how we listen as Indigenous, settler, and variously positioned subjects), but also to guide ... larger questions around the ontological and epistemological stakes of what listening is" (2). Hungry Listening examines North American settler colonialism's historic and ongoing (insatiable) appetite for appropriating Indigenous cultures, land, and, most centrally for purposes of the book, music and sound. Robinson considers how settler methods of listening, academic writing, and musicking are often carried into art music's interactions with Indigenous music and Peoples, typically with consequences that reinforce Eurocentric and colonial ways of being. Yet Hungry Listening is also a road map to and a celebration of those moments when music, listening, and Indigenous arts also provide spaces of Indigenous sovereignty and resurgence. Robinson maps art music's two warring impulses onto what he calls "inclusionary music," an idea drawing on Sara Ahmed's 2012 work, in which inclusionary does not have its usual positive connotation. In this context, "inclusionary" designates art music collaborations grounded in hungry listening that "fit" Indigenous People into "classical composition and performance systems," guided by "an interest in-and often a fixation upon-Indigenous content, but not Indigenous structure" (6). On the other hand, art music also offers the potentiality to work against hungry listening through what Robinson calls "Indigenous+art music," projects that "[foreground] a resistance to integration" in order to participate in "conjoining (rather than merging) two areas of sound practice" in ways that both reflect Indigenous ontologies and "[ask] how we as listeners attend to being between these ontologies and sound worlds" (9). Readers of this book are presented with the opportunity to learn how to productively engage with the relations between these two worlds, and therefore to work in solidarity with Indigenous Peoples in resolving and improving future relations.

Hungry Listening's Introduction, first two chapters, and "Writing Indigenous Space" section lay the intellectual and epistemological groundwork necessary to understand Robinson's musical arguments in chapters 3-5. "Hungry Listening," the book's opening chapter, examines how art music's colonial listening practices have given most listeners "tin ears" that "disallow us from understanding Indigenous song as both an aesthetic thing and as more-thansong" (45) and that frequently cause listeners trained in art music's listening practices to rest in aesthetic contemplation rather than engaging in and being mindful of the limits of their listening positionalities. Robinson draws on his own positionality to highlight his point: as a cis-gendered Stó:lō man, he does not listen to music with xwelítem ears, yet still must listen as a guest when listening to music on the Haudenosaunee and Anishinaabe lands where he resides, and where local understandings and traditions and protocols are not his own. Chapter 1 lays out a road map of how and when to engage in sonic realities that rest outside one's own lived experiences and knowledge as a culturally appropriate-but not culturally appropriative-guest. Chapter 2, "Writing about Musical Intersubjectivity," turns a critical eye on how music scholars write about music. Robinson examines how "sensate" and "apposite" writing methodologies might help us decolonize our practices of writing about 
music to destabilize the listening positionalities and experiences we assess as normative, allowing for movement towards a cultural and musical context that includes Indigenous resurgence and sovereignty (79). Notably, writing grounded in such methodologies also "provide[s] us with an aesthetic means toward writing intersubjectivity" (86), a form of relationality that is deeply rooted in Indigenous cultures and overlooked in most Westernized writing about music. Chapters 1 and 2 ultimately bring together music and words and challenge the reader to understand both differently.

Robinson writes the major portion of the book to a mixed audience of settler and Indigenous readers, but asks that his "Writing Indigenous Space" section $(27-36)$ be a space exclusively for Indigenous readers. This practice may feel uncomfortable for some. I would gently and respectfully suggest, particularly to white settler readers, that the opportunity to sit with, reflect on, and learn from that discomfort is one of Hungry Listening's most valuable lessons. Discomfort, the question of belonging, and the realization that a space has not been set up for or with you in mind are feelings and experiences that BIPOC students and scholars carry into most of academia's spaces. As a musicologist of Métis, Haida, and settler heritage, the opportunity this book gave me to share discursive space with Indigenous colleagues gave me hope that some of the loneliness and racism I have occasionally felt in the overwhelmingly white space of art music-making and academia will be lessened for colleagues still to come. They will inherit the sense of decolonized community Robinson and others are beginning to build, one settler readers are welcomed to share with us in the "Event Scores" Robinson writes between chapters (see 75-6, 107-12, 147-8, 191-200, 233-4), poetic writings that further a culture of decolonized academic writing about the arts. Robinson also invites settler perspectives into the book's dialogic community, through a written conversation about decolonial listening practices with scholars Deborah Wong and Ellen Waterman that features prominently in the conclusion (240-52).

The second half of the book, chapters $3-5$, builds on the book's foundations while moving to a discussion of art music composition and performance. Chapter 3, "Contemporary Encounters between Indigenous and Early Music," outlines a four-fold "Taxonomy of Musical Encounter" between Indigenous and settler art music (122-45) that moves from inclusionary music through to Indigenous+art music. The taxonomy includes the integration or inclusionary model; nation-to-nation music trading and reciprocal presentation; a combination of "modes of encounter"; and "structures that allow for a coexistence of difference that refuses integration" (123). Robinson's analysis will likely be deeply informative in considering how future collaborations or performances of already-existing music might further decolonize methods and approaches. Chapter 4, "Ethnographic Redress, Compositional Responsibility," summarizes art music's historic and ongoing practice of appropriating Indigenous musics through ethnographic song collection and usage of the songs in settler compositions. After recounting this history, Robinson focuses on "the different responsibilities and opportunities we ... have to the life of Indigenous song, incarcerated and trapped against its will in its current locations within the 
archive and within other classical music compositions" (150-1). Drawing particularly on the work of Peter Morin and Jeremy Dutcher to "cleanse" (167) stolen songs, Robinson challenges composers to participate in redress, to work towards a "decolonial reconceptualization of compositional practice that demonstrates responsibility to First Peoples' historical and social realities" (203). Chapter 5, "Feeling Reconciliation," examines how Canadian music performances that centre upon reconciliation create "affective responses to music" that are "experienced and described as felt forms of reconciliation" (204) by the settler Canadian public. However, these performances tend to present audiences with a model of reconciliation as "a return to positive feeling" (206) and "reconciliation-as-friendship" (207). In the process, these performances undermine Indigenous principles of reconciliation, including restorative justice and "fostering new alliances ... in nation-to-nation models of political sovereignty" (231). If we are serious about performing reconciliation through music, we must "acknowledge the privilege and power that we hold within our artistic and working communities, and then find ways to give over such power" (232).

Affectively and intellectually, Hungry Listening is not easy reading. The book's unflinching account of the artistic, cultural, epistemological, and genocidal violence routinely leveraged against and experienced by Indigenous Peoples is challenging to take in all at once (it is, of course, exponentially more challenging for Indigenous communities to live with) and will likely cause some discomfort for a settler readership. At the same time, while Robinson's deftness in bringing together Indigenous epistemologies and ontologies, music scholarship, sound studies, and critical theory marks an extraordinary intellectual achievement, I imagine his very fluency and rapidity in moving between these highly complex ideas might leave some readers behind-particularly, for example, undergraduate readers or readers without previous background in these topics. Yet if the intellectual cost of admission to this book is at times steep, it is emphatically a price worth paying for the understandings and knowledge readers will gain.

Robinson concludes by noting that his work offers "several strategies not only for decolonizing and resurgent listening, but for ... forms of writing that resist the epistemic violence of listening experiences.... What lies ahead must expand and refine new protocol for this work to benefit future generations" (258). Robinson's summation is in keeping with the concept of stewardship and its realization that the knowledge we possess is not only something we own and acquire, but also something we must care for and be accountable to. ${ }^{1}$ Such is the relationship I would suggest music and sound scholars ought to bring to Robinson's book. Ultimately, reading the book is only a first step, one towards acquisition of knowledge. Being stewards of the knowledge Robinson presents demands that it not only be acquired, but that it be felt, shared, experienced anew again and again when we listen, when we teach, when we hear. Hungry

1 For a particularly insightful overview and discussion of stewardship's application to scholarship and scholarly writing, and an explanation of the term's conceptual origins and usage in both Black and Indigenous communities, see Ange-Marie Hancock (2016, 21-3). 
Listening's insights should resound off Robinson's pages and into our classrooms, our listening, our music-making, our lives.

\section{REFERENCES}

Ahmed, Sara. 2012. On Being Included: Racism and Diversity in Institutional Life. Durham, NC: Duke University Press.

Cote-Meek, Sheila. 2014. Colonized Classrooms: Racism, Trauma and Resistance in Post-Secondary Education. Halifax: Fernwood Publishing.

Hancock, Ange-Marie. 2016. Intersectionality: An Intellectual History. Oxford: Oxford University Press.

Hoefnagels, Anna, and Beverley Diamond, eds. 2012. Aboriginal Music in Contemporary Canada: Echoes and Exchanges. Montreal and Kingston: McGill-Queen's University Press.

Robinson, Dylan, and Keavy Martin, eds. 2016. Arts of Engagement: Taking Aesthetic Action in and beyond the Truth and Reconciliation Commission of Canada. Waterloo, ON: Wilfrid Laurier University Press.

Wilson, Shawn. 2015. Research is Ceremony: Indigenous Research Methods. Halifax: Fernwood Publishing.

\section{BIOGRAPHY}

Rena Roussin is a Métis and settler music scholar and doctoral student in musicology at the University of Toronto. Her research examines historic and current forms of activism and constructions of intersectional identity in art music, particularly in opera and oratorio. Rena's publications appear in Haydn: The Online Journal of the Haydn Society of North America, Musicological Explorations, and the forthcoming Bloomsbury Handbook of Music and Art. 